\title{
Dance of the forest
}

\section{Biome \\ choreographed byJodi Lamask \\ premieres on 10 November in La \\ Gran Via, San Salvador}

\section{Michael Hopkin}

To a literalist, dance is a celebration of the human body. Of course, it can also allude to other organisms - even, in the case of San Francisco-based choreographer Jodi Lomask, to the relationships between them. Biome, a new work by Lomask's company Capacitor, has its premiere in San Salvador this week. Like her previous pieces, it began with research scientists - here including the tropical-tree ecologist Nalini Nadkarni - sharing their insights.

The result, Lomask stresses, does not attempt to convey scientific concepts; it uses the ideas as a jumping-off point. Audience members preoccupied with looking for metaphors will find themselves frustrated. The goal, says Lomask, is to "draw attention to open spaces and the importance of pristine biomes".

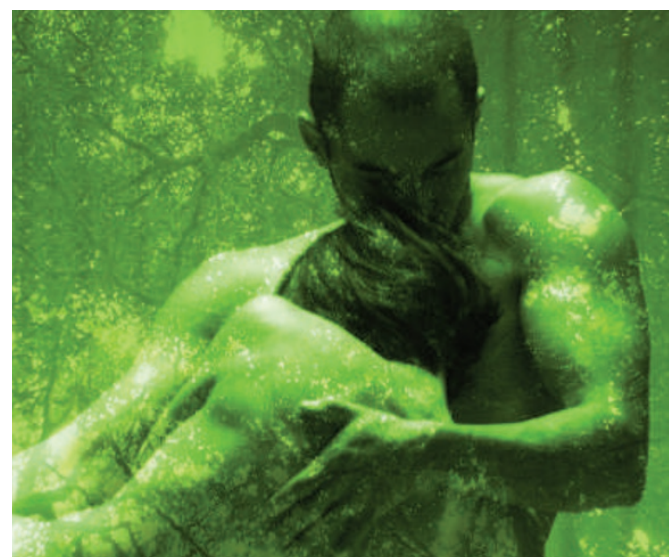

Ecological phenomena are strongly referenced in the show's preview film, shot in the Monteverde cloud forest of Costa Rica and screened at this year's meeting of the Ecological Society of America in San Jose, California. A naked dancer unfurls herself towards the Sun, capturing with uncanny precision the jerky grace of a plant in a time-lapse movie.
Another creeps, vine-like, up a huge tree; yet more lithe bodies cram themselves into a hollow trunk, like a colony of fungal parasites. "Both artists and scientists are working to show what's really there," says Lomask.

Engaging with the biological community is a change of direction for Capacitor. Her previous shows Digging in the Dark and Within Outer Spaces were inspired by geology and astrophysics. With performances at universities, theatres, nightclubs, schools, corporate events and fringe festivals, the company has reached a large number of people. The new show will add a shopping mall in Central America to that list.

Capacitor's next piece, called Urban Canopies, premieres in December 2008 at the opening of the new California Academy of Sciences building in Golden Gate Park.

Michael Hopkin is a senior news reporter for Nature.

View the preview at www.capacitor.org

\section{EXHIBITION}

\section{Demonic deeds in symbiotic art}

\section{Colin Martin}

"Science and natural history museums have increasingly become places of theatrical spectacle - venues for display in which negotiations for the meanings of objects take place," says Bergit Arends, curator of contemporary arts at London's Natural History Museum. The museum's spectacular hall, designed by Victorian architect Alfred Waterhouse, has certainly provided the public with its fair share of spatial drama since it opened in 1881. Now the evolving function of the museum is marked by a resident artist's exhibition.

Tessa Farmer got her inspiration for Little Savages from insects of the order Hymenoptera, which includes ants, bees, wasps and sawflies. She was captivated by the parasitic wasps, perceiving their similarity with the malevolent fairy creatures she has assembled from insect fragments over the past decade. Her exhibition has three parts: a sculptural intervention based on a stuffed fox; six beautifully observed pencil drawings of entomological subjects; and an animated film,
An Insidious Intrusion, in which demonic insect-fairies spear an unfortunate stag beetle with porcupine spines before sawing it into lifeless fragments.

Attacked from all sides, the fox has on its shoulders a bird grasping an insect in its beak, and what seems to be a crustacean clinging to its lower back. Swarms of insects hover around it: its ears are filled with larvae, pupae or wasp nests

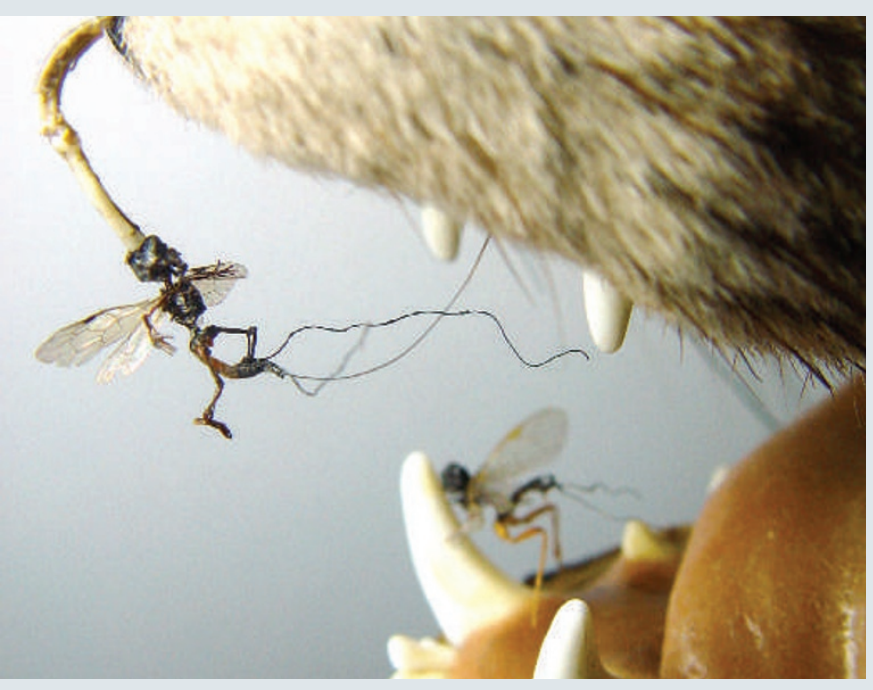
while another with similar intent says Gavin Broad, curator of hang from its abdomen, beetles infest its flank, and its matted brush resembles a wasp's nest made out of wool. On a finer scale, a parasitic fairy forces a ruby-tailed wasp to lay its eggs in the fox's nose, attempts to abseil into its mouth (pictured).

"Looking at parts of the collection with Tessa has made me think of it more as a treasure trove,"
Hymenoptera, in an endearingly frank account of his obsessive working life as an entomological taxonomist, "Tessa's fairies seem just as real as 'my' wasps."

Farmer's work imaginatively reinforces how the museum's entomological fieldwork has evolved from its nineteenth-century preoccupation with collecting insect specimens for pinning or pickling - it now has 28 million — into an institution that is researchdriven and focused on how insect communities interact ecologically.

"In the institutional ecology of the museum, artists and scientists can develop a relationship of mutual benefit," concludes Arends. "The role of artists is to disrupt engrained perceptions for the benefit of the museum, to change its course, and to reveal new knowledge in the process."

Colin Martin is a London-based science writer.

Little Savages is at the Natural History Museum in London until 27 January 2008. 